\title{
KELAPA SAWIT DAN PUNAHNYA BAHASA LOKAL
}

\author{
Sahril \\ Balai Bahasa Sumatera Utara
}

\begin{abstract}
Abstrak
Kehadiran kelapa sawit di tengah masyarakat sebenarnya adalah untuk menambah penghasilan bagi masyarakat setempat. Akan tetapi, di sebalik itu semua ada sektor yang dirugikan, yaitu lingkungan dan ekologi yang berdampak pada punahnya flora dan fauna setempat. Punahnya flora dan fauna berdampak pula pada punahnya bahasa lokal yang ada di daerah tersebut. Di antara bahasa yang punah adalah penamaan untuk flora dan fauna yang punah itu. Melalui kajian ekolinguistik ditemukan penyebab punahnya bahasa lokal. Dari hasil penelitian, ditemukan ada 49 nama flora dan fauna yang tidak lagi diketahui oleh penuturnya, khususnya di kalangan generasi muda.
\end{abstract}

Kata kunci: ekolinguistik-sawit dan bahasa lokal

\begin{abstract}
Palm presence in the community actually is to increase production for the local community. But behind it all there is the affected sectors, namely environmental and ecological impact on the local flora and fauna extinction. Extinction of flora and fauna in turn impact on the extinction of local languages in the area. Among the extinct language is the designation for the extinction of flora and fauna that. Through the study found ekolinguistik cause localized extinction. From the results of the research, found some 49 names of flora and fauna that are not yet known by the speakers, especially among the younger generation.
\end{abstract}

Keywords: ekolinguistik-palm and the local language 


\section{Pendahuluan}

Indonesia tercatat sebagai negara kedua yang paling banyak memiliki bahasa ibu setelah Papua New Guinea. Jumlah bahasa ibu di Indonesia ada 742, sedangkan untuk Papua New Guinea sejumlah 867. Dari 742 rumpun bahasa ibu yang ada di Indonesia separuhnya berada di Papua (Kompas, 13 Februari 2003). Hal ini wajar sebagaimana diungkap oleh A.F. Tucker (1987) bahwa di pedalaman Papua memang banyak sekali variasi subsukunya. Sebagai contoh orang Sentani, sukunya terbagi dalam tiga dialek bahasa, yaitu bahasa Sentani barat, timur, dan tengah. Orang Sentani Timur sering juga dikenal dengan orang Hedam. Demikian juga untuk orang Dani, terbagi dalam berbagai subsuku, ada Dani Baliem, Yamo, Toli, dan Sipak yang kesemuanya itu ternyata memiliki variasi bahasa.

Diyakini bahwa untuk bahasa-bahasa ibu atau bahasa lokal beberapa tahun ke depan akan semakin punah dan hilang. Menurut data UNESCO setiap tahun ada sepuluh bahasa daerah yang punah. Pada akhir abad 21 ini diperkirakan laju kepunahan akan lebih cepat lagi. Menurut laporan Kompas 13 Februari 2003, di antara 6.000 bahasa yang ada di dunia, hanya akan ada 600-3.000 bahasa menjelang akhir abad 21 ini. Dari 6.000 bahasa daerah itu, sekitar separuhnya adalah bahasa dengan jumlah penuturnya tidak sampai 10.000 orang. Padahal, salah satu syarat lestarinya bahasa adalah jika jumlah penuturnya mencapai 100.000 orang.

Bukti-bukti akan adanya kepunahan bahasa ibu di Indonesia adalah dari jumlah 109 bahasa daerah yang ada, ternyata jumlah penuturnya sudah kurang dari 100.000 orang, misalnya bahasa Tondano (Sulawesi), Ogan (Sumatera Selatan), dan Buru (Maluku). Bahkan menurut laporan Kompas November 2002 lalu, jumlah penutur bahasa Sunda di Bandung (bukan di Jawa Barat-nya) menurun jumlahnya karena imbas urbanisasi dan banyaknya migrasi masuk multi-etnik dan kontak dengan budaya lain. Selain itu, juga ada kecenderungan baru bahwa untuk kelas menengah baru sudah enggan menggunakan bahasa daerah yang terkesan kuno.

Di samping masalah sikap penutur, kepunahan bahasa lokal juga dapat disebabkan faktor lingkungan atau ekologi. Salah satu di antaranya adalah akibat rusaknya lingkungan, yang menyebabkan flora dan fauna pun akan punah juga. Salah satu penyebab rusaknya lingkungan tersebut adalah eksploitasi hutan menjadi perkebunan monokultur (tumbuhan yang semacam saja, misalnya kelapa sawit).

Kelapa sawit(Elaeis) adalah tumbuhan industripenting penghasil minyak masak, minyak industri, ataupun bahan bakar (biodiesel). Perkebunannya menghasilkan keuntungan besar sehingga banyak hutan dan perkebunan lama dikonversi menjadi perkebunan kelapa sawit. Indonesia adalah penghasil minyak kelapa sawit terbesar di dunia, yang penyebarannya meliputi daerah Aceh, pantai timur Sumatra, Jawa, dan Sulawesi.

Kendati kerusakan alam dan penggundulan hutan mencapai taraf mengkhawatirkan dengan segala dampaknya bagi Indonesia, pemerintah tampaknya belum berencana untuk menekan pertumbuhan lahan kelapa sawit di Indonesia. Permintaan komoditi sawit Indonesia justru mengalami peningkatan seiring dengan aktivitas perdagangan internasional yang makin marak atas komoditi ini. Namun, hal ini harus dibayar mahal dengan lenyapnya puluhan juta hektar hutan tropis Indonesia. Laporan Greenpeace berjudul "How the Palm Oil Industry is Cooking the Climate" menyatakan bahwa Indonesia sudan kehilangan 74 juta hektar hutan sejak 50 tahun terakhir untuk keperluan industri kehutanan, minyak kelapa 
sawit adalah salah satunya. Angka kehilangan hutan Indonesia hingga 2010 adalah sekitar 1,8 juta hektar per tahun. Dari segi kerugian ekologi lokal, berbagai fungsi ekologi hutan yang sebelumnya menyediakan pangan dan kehidupan bagi warga, kini semakin mandul akibat tercemar limbah pengolahan sawit, atau justru mengalami kekeringan akibat airnya terserap oleh perkebunan.

Selain itu, Indonesia juga terancam kehilangan puluhan bahkan ratusan spesies langka akibat alih fungsi hutan menjadi perkebunan sawit. Di Sumatera, angka harimau Sumatera kini tercatat tinggal 400 hingga 500 ekor, dengan tingkat konflik wilayah dengan manusia yang terus meningkat. Hal yang sama juga dialami gajah Sumatera yang semakin sering memasuki wilayah manusia. Di Kalimantan dan Sumatera, orangutan bahkan kini berada dalam kondisi terjepit, setelah jutaan hektar rumah mereka hilang. Kasus terakhir, seekor orangutan Kalimantan tewas setelah memasuki permukiman penduduk akibat tubuhnya mengalami luka bakar serius.

Satu spesies diperkirakan punah setiap harinya (KMNLH, 1997). Inventarisasi yang dilakukan oleh badan-badan internasional, seperti International Union for Conservation of Nature and Natural Resources (IUCN) dapat dijadikan indikasi tentang keterancaman spesies. Pada 1988 sebanyak 126 spesies burung, 63 spesies binatang lainnya dinyatakan berada diambang kepunahan (BAPPENAS, 1993).

Pada 2002, Red data List IUCN menunjukan 772 jenis flora dan fauna terancam punah, yaitu terdiri atas 147 spesies mamalia,114 burung, 28 reptilia, 68 ikan, 3 moluska, dan 28 spesies lainnya serta 384 spesies tumbuhan. Salah satu spesies tumbuhan yang barubaru ini juga dianggap telah punah adalah ramin (Gonystylus bancanus). Spesies tersebut sudah dimasukkan ke dalam Appendix III Convention of International Trade of Endengered Species of Flora and Fauna (CITES). Sekitar 240 spesies tanaman dinyatakan mulai langka, di antaranya banyak yang merupakan kerabat dekat tanaman budidaya. Paling tidak 52 spesies keluarga anggrek (Orchidaceae) dinyatakan langka.

Kepunahan jenis di Indonesia terutama disebabkan oleh degradasi habitat (deforestasi, perubahan peruntukan lahan), bencana (kebakaran), eksploitasi secara tidak bijaksana (perburuan/pemanenan liar) dan masuknya spesies asing invasif serta perdagangan satwa liar.

Tulisan ini berusaha mengungkapkan bahwa salah satu penyebab punahnya bahasa lokal di Sumatera Utara adalah akibat eksploitasi hutan atau lahan menjadi perkebunan kelapa sawit.

Ada dua sumber data dalam penelitian ini, yaitu data yang diperoleh secara langsung dari lapangan (data primer), yaitu di Kabupaten Asahan dan data dari berbagai instansi yang relevan dengan maksud dan tujuan penelitian ini (data sekunder). Data primer merupakan hasil dari wawancara terhadap masyarakat tempat lokasi penelitian ini dilakukan. Sementara itu data sekunder diambil dari berbagai sumber yang berkaitan dengan tujuan penelitian ini.

Data yang menjadi sasaran dalam penelitian ini adalah nama-nama flora dan fauna yang terdapat di Kabupaten Asahan. Nama-nama flora dan fauna dimaksud adalah sebutan dalam bahasa lokal, yaitu bahasa Melayu dialek Asahan.

Data dikumpulkan dalam bentuk data kuantitatif, yaitu jumlah flora dan fauna yang dahulunya terdapat di daerah mereka, tetapi setelah adanya perkebunan kelapa sawit, flora dan fauna tersebut mulai menghilang bahkan tidak pernah mereka lihat lagi. Data tersebut 
diperoleh secara langsung dari lapangan melalui wawancara secara mendalam.

Setelah data terkumpul, peneliti berusaha mencari gambar atau foto yang berkaitan dengan flora dan fauna tersebut. Selanjutnya, peneliti memilih 30 responden, yang terdiri atas 10 orang siswa SD, 10 orang siswa SMP, dan 10 orang siswa SMA. Penulis meminta kepada responden untuk menyebutkan nama flora dan fauna tersebut dalam bahasa daerah mereka (Melayu dialek Asahan).

Data yang berupa jawaban dari responden diolah dengan komputer guna mendapatkan tabel, grafik, dan lainnya. Perhitungan juga dilakukan melalui komputer.

Penelitian ini menggunakan metode penelitian kuantitatif dan kualitatif. Berdasarkan data kuantitatif akan diperoleh data kualitatif lebih bersifat deskriptif atau interpretatif. Analisis data kuantitatif mengarah pada pendapat responden terhadap data yang diajukan, sedangkan analisis kualitatifnya bersifat inferens; yaitu berupa pandangan dan kebijakan penguasa terhadap fenomena yang terjadi dari data kuantitatif tersebut.

Landasan teori penelitian ini adalah ekolinguitik. Ekolinguistik adalah suatu disiplin ilmu yang mengkaji lingkungan dan bahasa. Ekolinguistik merupakan ilmu bahasa interdisipliner, menyanding ekologi dan linguistik (Mbete, 2009:1). Berdasarkan hal itu bahasa sangat berkaitan erat dengan lingkungannya sendiri. Bahasa tersebut bisa hilang atau musnah apabila ekologi yang menunjangnya musnah pula.

Ekologi bahasa adalah ilmu yang mempelajari interrelasi antara bahasa yang ada dalam kognitif manusia dan dalam komunitas yang multilingual. Semenjak itu, ekolinguistik sebagai cabang ilmu linguistik mengembangkan hubungan antara bahasa dan ekologi yang telah didirikan dengan cara yang berbeda serta dengan menggunakan pendekatan dan metode yang berbeda pula (Jorgensen dan Bendoricchio, 2001).

Ekologi merupakan ilmu yang muncul akhir abad IX di Eropa dan Amerika. Ilmu ekologi kelihatannya tidak hanya lingkungan manusia sebagai objek kajiannya, tetapi mempelajari banyak hal yakni kompleksitas interaksi sejumlah komponen abiotik seperti udara, dan air, serta komponen biotik, seperti tumbuhan, hewan. Ekologi manusia membangun interaksi antara manusia dan lingkungannya, dengan sangat menambah kompleksitasnya. Ekologi manusia dibatasi oleh alam dan budayanya. (Merchant, 1992)

Selanjutnya, konsep ekologi menurut Thohir, (dalam Mbete, 2010:2) adalah ilmu yang mempelajari semua jenis makhluk hidup, termasuk manusia (dengan budaya dan bahasanya) dan kaitannya dengan "lingkungannya". Selanjutnya yang dimaksud dengan lingkungan manusia atau lingkungan hidup adalah segala sesuatu yang berada di sekitar manusia, baik yang berwujud benda mati maupun jasad-jasad atau organisme-organisme dan di dalamnya ada manusia.

Secara umum Louis dan Calvet (2006) mendefinisikan ekologi sebagai ilmu yang mempelajari relasi antara organisme dan lingkungannya, sedangkan ekologi bahasa adalah ilmu yang mempelajari bahasa dan lingkungannya, dalam hal ini, relasi antara bahasa itu sendiri, serta antara bahasa dan masyarakat. Bahasa mempunyai relasi dengan ekologi yang cukup tinggi dan sulit dipisahkan. Keberagaman atau kebervariasian bentuk leksikon, bentuk gramatika, bentuk teks, budaya dengan ekologinya, mencerminkan interaksi atau relasi suatu bahasa dan ekologinya. Seperti yang dinyatakan Derni (2008) bahwa ekolinguistik adalah ilmu yang mempelajari bahasa dengan lingkungan yang memiliki intrarelasi, interrelasi, ekstrarelasi, dan kombinasi satu sama lain di antara unsur-unsur tersebut. 


\section{Hasil dan Pembahasan}

\subsection{Sawit dan Rusaknya Hutan}

Provinsi Sumatera Utara terdiri atas 25 Kabupaten dan 8 Kota, dengan luas 72.981,23 $\mathrm{km}$ persegi. Luas perkebunan kelapa sawit adalah 855.333 ha. Salah satu kabupaten yang terdapat di Provinsi Sumatera Utara adalah Kabupaten Asahan, yang merupakan lokasi penelitian ini. Kabupaten Asahan dengan luas 3.702,21 km persegi terdiri atas 13 kecamatan, 15 kelurahan, dan 158 desa. Jumlah penduduknya 896.914 jiwa (data 2012). Di daerah ini terdapat $125.324,21$ ha luas perkebunan kelapa sawit milik pemerintah, swasta, dan swasta asing. Sementara itu, perkebunan kelapa sawit rakyat menguasai lahan seluas 60.997 ha. Asahan merupakan produksi ketiga terbesar penghasil kelapa sawit di Sumatera Utara setelah Labuhanbatu dan Tapanuli Selatan.

Pada mulanya perkebunan tersebut merupakan hutan yang bukan termasuk hutan lindung. Di dalam hutan itu terdapat berbagai macam flora dan fauna yang hidup. Akan tetapi, ketika hutan-hutan itu berubah fungsi menjadi perkebunan kelapa sawit, baik perkebunan milik perusahaan swasta maupun perkebunan milik rakyat, perlahan flora dan fauna pun menghilang. Hal ini dikarenakan sifat kebun yang hanya ditanami satu jenis tanaman (homogen), yaitu kelapa sawit. Akhirnya, mau tidak mau berbagai tumbuhan liar habis ditebang sehingga membuat para binatang pun kehilangan makanannya. Lambat laun, para binatang itu pun mati ataupun berpindah ke tempat lain.

Dampak negatif yang terungkap dari aktivitas perkebunan kelapa sawit bagi ekologi di antaranya adalah sebagai berikut. (a) Keanekaragaman hayati: persoalan tata ruang, monokultur, homogenitas, dan overloads konversi yang mengancam keanekaragaman hayati karena pengembangan perkebunan kelapa sawit. Usulan kawasan monokultur yang sangat luas untuk kelapa sawit dapat mengancam musnahnya keanekaragaman hayati legendaris; (b) Kerusakan hutan: pembukaan lahan sering kali dilakukan dengan cara tebang habis dan land clearing dengan cara pembakaran demi efisiensi biaya dan waktu; (c) Kerakusan unsur hara dan air tanaman monokultur seperti sawit, di mana dalam satu hari satu batang pohon sawit bisa menyerap 12 liter air tanah; (d) Emisi karbon: CPO yang digunakan untuk biodisel akan menyebabkan kerusakan hutan akibat konversi menjadi perkebunan kelapa sawit; (e) Seleksi alam: munculnya hama migran baru yang sangat ganas karena jenis hama baru ini akan mencari habitat baru akibat kompetisi yang keras dengan fauna lainnya. Ini disebabkan oleh keterbatasan lahan dan jenis tanaman akibat monokulturasi; (f) Bencana alam: selanjutnya, praktik konversi hutan alam untuk pembangunan perkebunan kelapa sawit seringkali menjadi penyebab utama bencana alam seperti banjir dan tanah longsor. Dampak negatif terhadap lingkungan menjadi bertambah serius karena dalam praktiknya pembangunan perkebunan kelapa sawit tidak hanya terjadi pada kawasan hutan konversi, tetapi juga dibangun pada kawasan hutan produksi, hutan lindung, dan bahkan di kawasan konservasi yang memiliki ekosistem yang unik dan mempunyai nilai keanekaragaman hayati yang tinggi; (g) Polusi: permasalahan utama dengan minyak kelapa sawit sebagai biodiesel terletak pada bagaimana tanaman tersebut diolah, yaitu limbah minyak padat, fiber kelapa sawit, dan batok, serta limbah yang merusak dari minyak kelapa sawit, yaitu campuran polusi dari batok yang hancur, air, dan residu lemak, yang mempunyai dampak negatif pada ekosistem aquatik. Lebih jauh lagi, penggunaan pestisida, herbisida, dan pupuk berbasis petroleum secara bebas membuat keyakinan bahwa kebanyakan pengolahan minyak 
kelapa sawit tidak hanya menyebabkan polusi pada tingkat lokal, tetapi juga berkontribusi pada emisi gas rumah kaca; (h) Kerusakan tanah: perkebunan di Indonesia sangat merusak karenanya setelah 25 tahun masa panen lahan kelapa sawit kebanyakan ditinggalkan dan menjadi semak belukar. Tanah mungkin akan kehabisan nutrisi, terutama pada lingkungan yang mengandung asam sehingga beberapa tanaman mungkin tumbuh, menjadikan wilayah tersebut tanpa vegetasi, selain rumput-rumput liar yang akan mudah sekali terbakar.

Kenyataan tersebut, juga terjadi di daerah Kabupaten Asahan yang menjadi lokasi penelitian ini. Beberapa hutan produksi yang dijadikan lahan perkebunan kelapa sawit mengalami kejadian yang sama dialami oleh daerah lainnya di Indonesia.

\subsection{Punahnya Flora dan Fauna}

Pada tahun 2007, Menteri Lingkungan Federal Jerman Sigmar Gabriel, memperkirakan bahwa sampai 30\% dari semua spesies akan punah pada tahun 2050 (Gabriel, 2007). Dari jumlah tersebut, sekitar seperdelapan jenis tumbuhan dikenal terancam punah. ${ }^{1}$ Perkiraan mencapai setinggi 140.000 spesies per tahun (berdasarkan Spesies-area teori dalam Pimm, 1995). Angka ini menunjukkan praktik-praktik ekologi yang tidak berkelanjutan karena beberapa spesies muncul setiap tahun. Hampir semua ilmuwan mengakui bahwa laju kehilangan spesies lebih besar sekarang daripada setiap saat dalam sejarah manusia, dengan kepunahan terjadi pada tingkat ratusan kali lebih tinggi dari tingkat kepunahan latar belakang. Pada 2012, beberapa studi menunjukkan bahwa $25 \%$ dari semua spesies mamalia bisa punah dalam 20 tahun. ${ }^{2}$

Jared Diamond menggambarkan "Kuartet Jahat" dari perusakan habitat, berlebihan, spesies diperkenalkan, dan kepunahan sekunder (Sanderson, 1998). Edward O. Wilson lebih memilih akronim Hippo, berdiri untuk perusakan habitat, spesies invasif, polusi, populasi manusia lebih, dan lebih-panen (Jim Chen, 2003). ${ }^{3}$ Klasifikasi yang paling otoritatif yang digunakan saat ini adalah IUCN. Klasifikasi Ancaman langsung ${ }^{4}$ yang telah diadopsi oleh organisasi-organisasi konservasi internasional seperti Nature Conservancy AS, World Wildlife Fund, Conservation International, dan Birdlife International.

Kerusakan habitat telah memainkan peran penting dalam kepunahan, terutama terkait dengan kerusakan hutan tropis (Paul dan Anne, 1981). Faktor yang berkontribusi terhadap hilangnya habitat adalah kelebihan penduduk dan penggundulan hutan (Drakare, dkk., 2006), pencemaran (polusi udara, polusi air, pencemaran tanah), dan pemanasan global atau perubahan iklim.

Ukuran habitat dan jumlah spesies secara sistematis terkait. Spesies secara fisik lebih besar dan mereka yang tinggal di lintang rendah, di hutan, atau lautan lebih sensitif terhadap pengurangan di daerah habitat. ${ }^{5}$ Konversi ke "sepele" ekosistem standar (misalnya, monokultur berikut deforestasi) secara efektif menghancurkan habitat spesies yang lebih beragam yang mendahului konversi. Di beberapa negara tidak memiliki hak milik atau hukum longgar/ penegakan peraturan selalu menyebabkan hilangnya keanekaragaman hayati (biaya degradasi harus didukung oleh masyarakat).

Sebuah studi tahun 2007 yang dilakukan oleh National Science Foundation menemukan bahwa keanekaragaman hayati dan keanekaragaman genetik kodependen, keragaman

Reid Reversing loss of Biodiversity". Ag.arizona.edu. Diakses pada 21 Juni 2009. (http://id.wikipedia.org/ wiki/Keanekaragaman_hayati\#cite_note-Reid_Reversing_loss_of_Biodiversity)

2 Researches find threat from biodiversity loss equals climate change threat ", (Winnipeg Free Press), 7 Juni 2012. (http://id.wikipedia.org/wiki/Keanekaragaman_hayati\#)

48 | Ranah, Volume 2, Nomor 1, Juli 2013 
di antara spesies, membutuhkan keanekaragaman dalam satu spesies, dan sebaliknya. "Jika salah satu jenis dihapus dari sistem, siklus dapat mengurai, dan masyarakat menjadi didominasi oleh satu spesies." Saat ini, sebagian besar ekosistem yang terancam ditemukan di air tawar, menurut Millennium Ecosystem, Penilaian 2005 yang dikonfirmasikan oleh "Penilaian Air Tawar Hewan Ikan", yang diselenggarakan oleh platform keanekaragaman hayati, dan Institut Prancis de pour le Développement halus (MNHNP).

Melihat fenomena yang terjadi di dunia global yang digambarkan oleh para peneliti, setidaknya dapat menjadi pembelajaran bagi bangsa kita dalam hal pemeliharaan ekosistem yang berkaitan dengan pengembangan industri perkebunan kelapa sawit yang notabene sangat buruk dampak negatifnya terhadap lingkungan dan akhirnya memusnahkan flora dan fauna.

\subsection{Sawit dan Bahasa Lokal}

Setelah menguraikan dampak negatif akibat kelapa sawit, berikut ini akan diuraikan pula bagaimana hubungan kelapa sawit dengan punahnya bahasa lokal. Maksud dari punahnya bahasa lokal ini adalah berkaitan dengan punahnya flora dan fauna di daerah tersebut. Sejumlah nama flora dan fauna yang hadir di tengah masyarakat setempat selama ini, akhirnya akibat tidak pernah dilihat oleh masyarakat lagi khususnya oleh generasi mudanya, mau tidak mau penyebutan nama flora dan fauna itu pun menghilang dalam bahasa daerah mereka.

Berdasarkan hasil wawancara kepada 12 orang informan, (informan sengaja dipilih yang sudah berumur 60 tahun ke atas dan bertempat tinggal di sekitar perkebunan kelapa sawit) ditemukan bahwa dahulunya di daerah tersebut ditemukan jenis flora dan fauna sebelum adanya kebun kelapa sawit. Akan tetapi setelah maraknya perkebunan kelapa sawit, flora dan fauna itu tidak ditemukan lagi. Hanya mereka (para informan) yang mengetahui nama flora dan fauna itu dalam bahasa lokal mereka.

\begin{tabular}{|c|c|c|}
\hline No. & Jenis & Jumlah \\
\hline \multicolumn{3}{|c|}{ Kelompok Fauna } \\
\hline 1. & 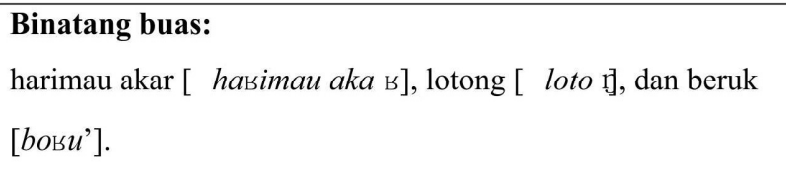 & 3 \\
\hline 2. & 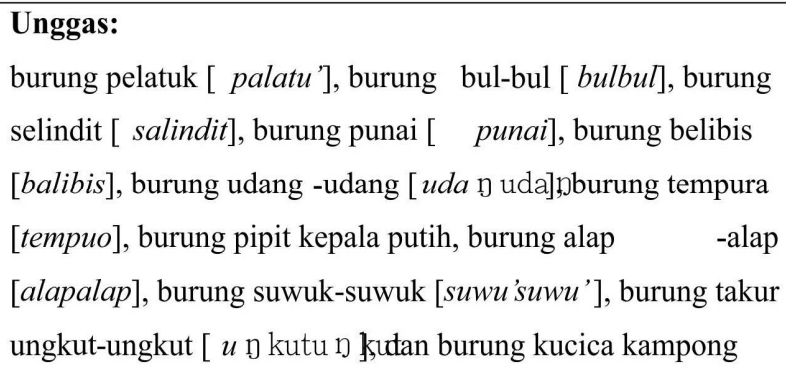 & 12 \\
\hline
\end{tabular}

3 Hippo dilemma". Windows on the Wild: Science and Sustainabiliy. New Africa Books. 7 September 2005. ISBN 1-86928-380-5. (http://id.wikipedia.org/wiki/Keanekaragaman_hayati\#)

4 IUCN's Classification of Direct Threats". Conservationmeasures.org. Diakses pada 24 September 2011. (http://id.wikipedia.org/wiki/Keanekaragaman_hayati\#)

5 Study: Loss Of Genetic Diversity Threatens Species Diversity". Enn.com. 26 September 2007. Diakses pada 21 Juni 2009. (http://id.wikipedia.org/wiki/Keanekaragaman_hayati\#) 


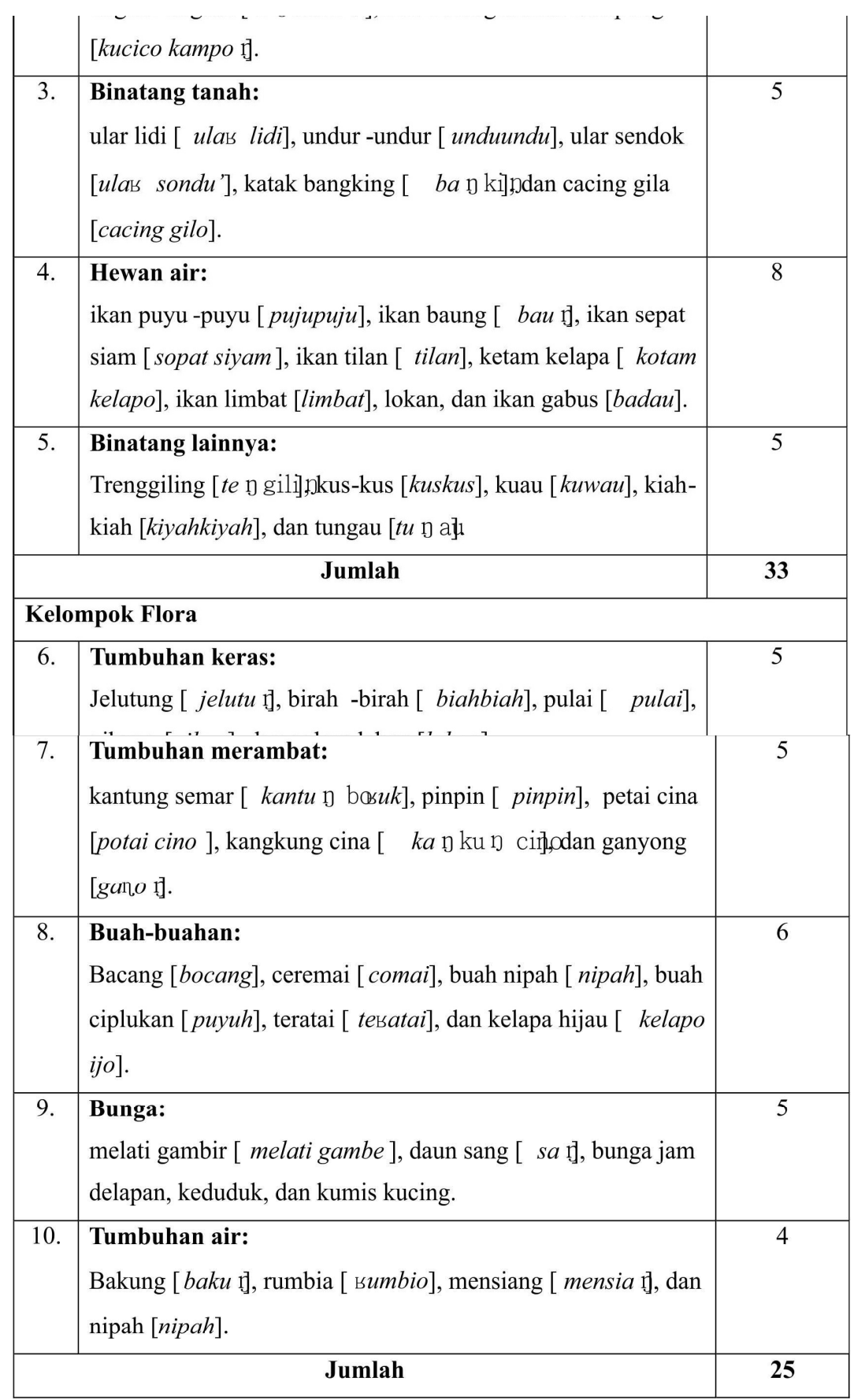

Dari 33 jenis fauna dan 25 jenis flora, peneliti berusaha mencari fotonya melalui internet. Kemudian menempelkannya pada lembar kertas, tanpa menuliskan namanya. Selanjutnya, peneliti melakukan uji tanya kepada para responden yang berjumlah 30 orang. Uji tanya ini dilakukan dengan memperlihatkan gambar flora dan fauna tersebut. Kemudian diminta kepada responden untuk menyebutkannya dalam bahasa daerah (BD) mereka dan dalam bahasa Indonesia (BI). Kemudian, kepada responden juga ditanyakan apakah mereka pernah $(\mathrm{Pn})$ atau tidak pernah (TPn) melihat flora dan fauna tersebut. Jika pernah melihatnya, di mana, apakah di daerah mereka (DM) atau melalui media (Md). 
Berikut ini adalah hasil uji tanya kepada 10 responden yang merupakan siswa SD, terdiri atas 6 responden laki-laki dan 4 responden perempuan. Masing-masing berasal dari kelas IV sebanyak 2 responden, kelas V sebanyak 3 responden, dan kelas VI sebanyak 5 responden. Responden berasal dari lima SD yang ada di sekitar perkebunan kelapa sawit. Mereka dipilih dari siswa yang berprestasi. Setiap responden ditanya secara terpisah.

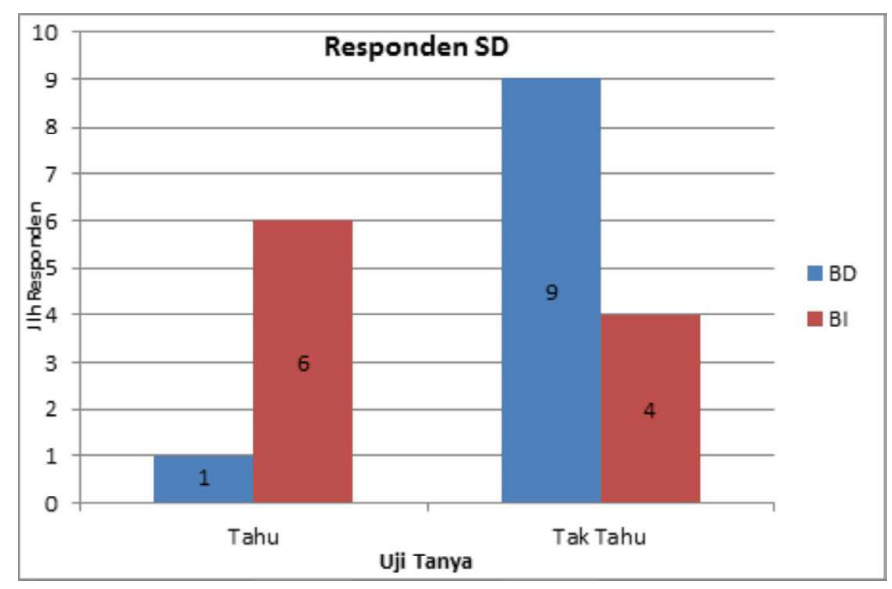

Grafik 1: Uji Tanya Nama Flora dan Fauna

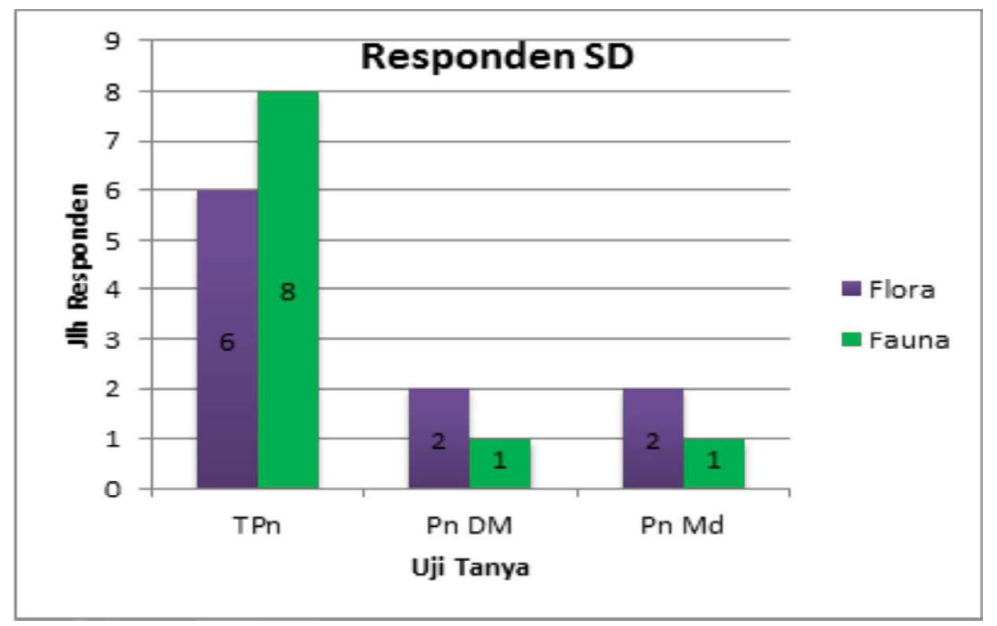

Grafik 2: Uji Tanya Pernah dan tidak pernah melihat Flora dan Fauna

Berdasarkan grafik 1 dan 2 di atas, terlihat bahwa dari segi nama flora dan fauna hanya 1 orang responden yang mengetahui namanya dalam bahasa daerah, sementara untuk bahasa Indonesia ada sebanyak 6 responden yang mengetahuinya. Sementara untuk uji tanya pernah dan tidak pernah melihatnya ada 6 responden tidak pernah melihat jenis flora itu lagi, 2 responden pernah melihatnya di daerah mereka dan 2 responden pernah melihatnya di media televisi. Selanjutnya untuk fauna 8 responden tidak pernah melihatnya lagi, 1 responden pernah melihatnya di daerah mereka dan 1 responden pernah melihatnya melalui media televisi.

Hasil uji tanya kepada 10 responden yang merupakan siswa SMP, terdiri atas 5 responden laki-laki dan 5 responden perempuan. Masing-masing berasal dari kelas VII 
sebanyak 3 responden, kelas VIII sebanyak 3 responden, dan kelas IX sebanyak 4 responden. Responden berasal dari dua SMP, yaitu SMP negeri dan SMP swasta yang lokasi sekolahnya berdekatan dengan area perkebunan kelapa sawit. Kesemua responden dipilih berdasarkan siswa yang berprestasi.

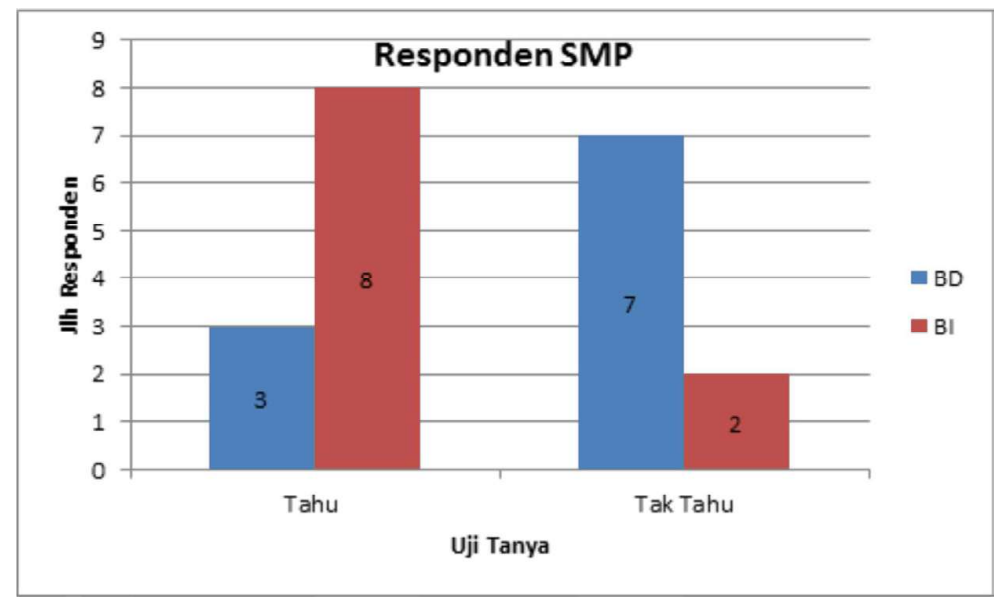

Grafik 3: Uji Tanya Nama Flora dan Fauna

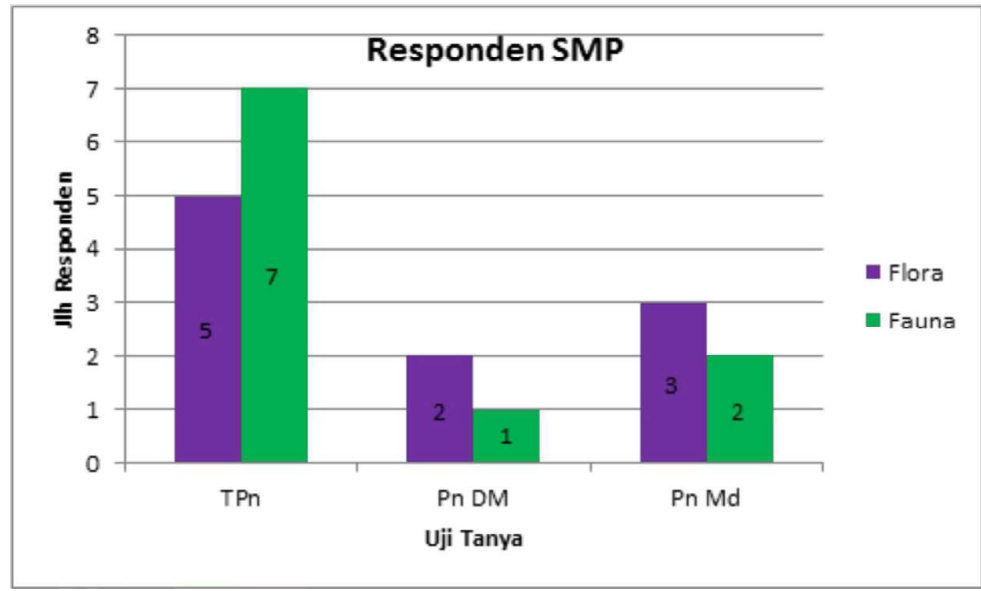

Grafik 4: Uji Tanya Pernah dan tidak pernah melihat Flora dan Fauna

Berdasarkan grafik 3 dan 4, terlihat bahwa dari segi nama flora dan fauna ada 3 orang responden yang mengetahui namanya dalam bahasa daerah, sementara untuk bahasa Indonesia ada sebanyak 8 responden yang mengetahuinya. Sementara untuk uji tanya pernah dan tidak pernah melihatnya, ada 5 responden tidak pernah melihat jenis flora itu lagi, 2 responden pernah melihatnya di daerah mereka dan 3 responden pernah melihatnya di media televisi. Selanjutnya untuk fauna, 7 responden tidak pernah melihatnya lagi, 1 responden pernah melihatnya di daerah mereka, dan 2 responden pernah melihatnya melalui media.

Hasil uji tanya kepada 10 responden yang merupakan siswa SMA, terdiri atas 5 responden laki-laki dan 5 responden perempuan. Masing-masing berasal dari kelas $X$ sebanyak 3 responden, kelas XI sebanyak 3 responden, dan kelas XII sebanyak 4 responden. Mereka berasal dari dua SMA, yaitu SMA negeri dan SMA swasta, tetapi lokasi sekolahnya 
sudah berada di kecamatan, agak jauh dari lokasi perkebunan kelapa sawit. Hal ini dikarenakan oleh belum adanya SMA di lokasi perkebunan. Mereka juga dipilih dari siswa yang berprestasi.

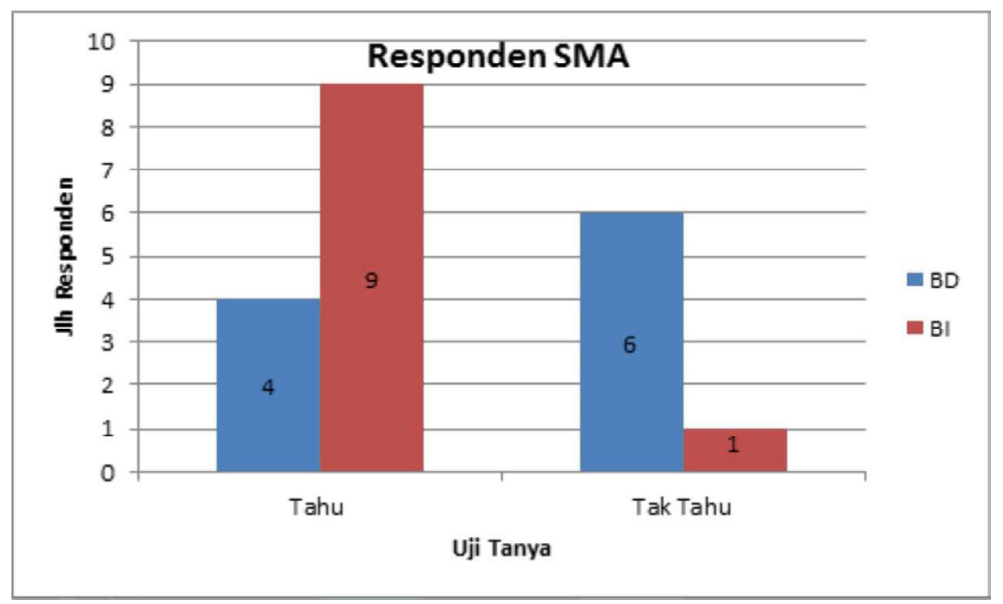

Grafik 5: Uji Tanya Nama Flora dan Fauna

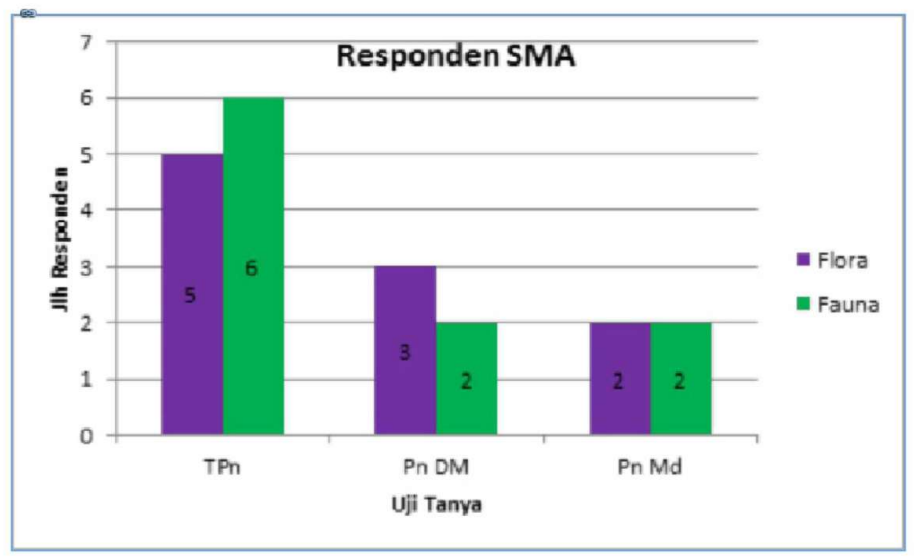

Grafik 6: Uji Tanya Pernah dan tidak pernah melihat Flora dan Fauna

Berdasarkan grafik 5 dan 6, terlihat bahwa dari segi nama flora dan fauna ada 4 orang responden yang mengetahui namanya dalam bahasa daerah, sementara untuk bahasa Indonesia ada sebanyak 9 responden yang mengetahuinya. Sementara untuk uji tanya pernah dan tidak pernah melihatnya, ada 5 responden tidak pernah melihat jenis flora itu lagi, 3 responden pernah melihatnya di daerah mereka, dan 2 responden pernah melihatnya di media televisi. Selanjutnya untuk fauna, 6 responden tidak pernah melihatnya lagi, 2 responden pernah melihatnya di daerah mereka dan 2 responden pernah melihatnya melalui media televisi.

Berdasarkan uji tanya kepada 30 responden, diperoleh jawaban bahwa sebanyak 22 responden tidak mengetahui nama flora dan fauna dalam bahasa daerah mereka. Hanya 8 responden yang dapat menyebutkan nama flora dan fauna dalam bahasa daerah mereka. Ironisnya lagi, sebanyak 19 responden tidak pernah melihat jenis flora yang pernah ada di daerah mereka dan sebanyak 21 responden juga tidak pernah melihat jenis fauna yang 
pernah ada di daerah mereka.

Apabila dilihat dari jumlah jenis flora dan fauna yang diajukan, di antara 58 jenis flora dan fauna yang diujitanyakan, hanya 8 responden atau $13.79 \%$ yang mengetahuinya dalam bahasa daerah mereka. Sangat disayangkan juga, ternyata dari 8 responden yang mengetahuinya dalam bahasa daerah mereka, dominan pada jenis flora dan fauna yang sama. Ada 7 responden menyebutkan nama jenis flora dan fauna yang sama dalam bahasa daerah mereka, hanya 1 responden yang berbeda.

Selanjutnya, ada 7 responden yang pernah melihat jenis flora dan 4 responden pernah melihat fauna di daerah mereka sendiri. Ketika ditanya waktu mereka pernah melihatnya, umumnya responden mengatakan 5 tahun sebelumnya. Ketika ditanya, apakah saat sekarang ini pernah melihatnya lagi, kesemua responden menjawab tidak pernah.

Berdasarkan hasil uji tanya terhadap responden tersebut, di sini sudah terlihat bahwa beberapa kosakata yang berkaitan dengan nama flora dan fauna dalam bahasa Melayu dialek Asahan sudah mengalami proses kehilangan. Kalangan generasi muda sudah tidak tahu lagi kosakata-kosakata untuk penyebutan nama flora dan fauna dimaksud. Hal ini jika dibiarkan secara berkelanjutkan tanpa ada upaya untuk pelestarian dan kebijakan dari pemerintah berkaitan dengan pengembangan industri perkebunan kelapa sawit, lambat laun keberadaan bahasa daerah yang berkaitan dengan penamaan flora dan fauna akan punah.

Fenomena ini ditambah lagi bahwa di daerah tersebut sekarang orang tua cenderung enggan menggunakan bahasa daerah dan hanya menggunakan bahasa Indonesia. Mereka beranggapan bahwa untuk maju anak harus bisa berbahasa nasional.

Menurut Kloss (1994), yang dikutip Herman (diunduh 12 September 2012), kepunahan bahasa itu dapat disebabkan pula oleh tiga hal: (1) kepunahan bahasa tanpa pergeseran bahasa (guyup tuturnya lenyap); (2) kepunahan bahasa karena pergeseran bahasa (guyup tutur tidak berada dalam "wilayah tutur yang kompak" atau bahasa itu menyerah pada pertentangan intrinsik prasarana budaya modern yang berdasarkan teknologi; dan (3) kepunahan bahasa nominal melalui metamorfosis (misalnya, sebuah bahasa yang turun derajat statusnya menjadi status dialek karena guyup tuturnya tidak lagi menulis dalam bahasa tersebut, tetapi mulai menulis dengan bahasa lain).

Secara umum, kelapa sawit bukanlah tanaman yang tidak baik. Namun, cara pengelolaan yang dilakukan oleh perusahaan perkebunan sering menyebabkan masalah lingkungan dan sosial yang tidak bisa dihindari. Tulisan ini bukan suatu advokasi agar kelapa sawit perlu ditinggalkan sebagai suatu instrumen pertumbuhan di Sumatera Utara, tetapi pelaku industri dan pemerintah harus belajar dari kesalahan yang dibuat di tempat lain dan menggunakan praktik-praktik yang berkelanjutan, pemerataan, dan ramah lingkungan.

Berbagai hasil penelitian menunjukkan bahwa ketika hutan berubah menjadi perkebunan kelapa sawit, sekitar $80--100 \%$ reptil, mamalia, dan berbagai jenis burung yang sebelumnya mendiami hutan sekarang tidak bisa lagi hidup di lingkungan yang baru itu. Perkebunan, dan "bahaya" yang beriringan bersamanya seperti aktivitas penebangan dan kebakaran menghancurkan habitat binatang. Hal inilah yang lambat laun menyebabkan punahnya juga bahasa lokal yang ada di daerah tersebut, khususnya dalam penyebutan nama flora dan fauna yang punah tersebut. 


\section{Simpulan}

Berdasarkan analisis di atas, dapat disimpulkan sekaligus sebagai rekomendasi kepada pemerintah, khususnya pemerintah daerah berkaitan dengan perkebunan kelapa sawit. Beberapa simpulan dan rekomendasi tersebut adalah sebagai berikut.

a. Perkebunan kelapa sawit harus dibangun di lahan-lahan tidur. Jangan ada lagi hutan yang dikonversi untuk perkebunan.

b. Izin-izin untuk perkebunan yang masih belum difungsikan (perusahaan tidak aktif, lahan terlantar) perlu dicabut, dikaji kembali, dan perlu didaftarkan kembali ke dalam daftar lahan yang tersedia untuk pengembangan perkebunan. Izin-izin yang berada di kawasan tanah gambut harus direlokasi ke kawasan lahan tidur.

c. Ketika izin untuk areal perkebunan yang baru diberikan kepada perusahaan perkebunan, analisis dan studi mengenai dampak terhadap suaka margasatwa harus dilakukan secara lebih mendalam dan kawasan hutan harus dibiarkan tidak tersentuh dalam memastikan perlindungan terhadap flora dan fauna.

d. Pembersihan lahan harus menghormati adat-istiadat setempat dan sebelumnya harus diperoleh "persetujuan, sepengetahuan, dan pemberitahuan" dari pemilik lahan. Pembakaran tidak pernah bisa digunakan sebagai suatu metode pembersihan lahan.

e. Perkebunan dan pabrik pengolahan kelapa sawit harus mengurangi penggunaan bahan-bahan kimia dalam tahap pertumbuhan dan pengolahan serta memastikan bahwa petunjuk-petunjuk ramah lingkungan dilaksanakan. Pemerintah harus meminta daftar dari jenis pestisida dan herbisida dan berbagai bentuk bahan kimia lain yang akan digunakan serta penjelasan tentang pencegahan risiko yang akan dilakukan dalam mengurangi risiko kesehatan bagi para pekerja dan masyarakat setempat, serta memastikan dampak lingkungan yang minimal. Permohonan izin bisa ditolak apabila informasi yang dibutuhkan tidak jelas atau di bawah standar.

f. Ada baiknya bahasa daerah yang terancam punah itu diolah menjadi buku dan mulai diajarkan sebagai materi ajar muatan lokal. Dengan demikian, sedikit-demi sedikit, bahasa dan budaya yang terancam punah itu mulai dikenal lagi oleh generasi muda.

Demikianlah beberapa simpulan dan sekaligus berupa rekomendasi kepada pihak pemerintah berkaitan dengan perkebunan kelapa sawit dan punahnya bahasa lokal. 


\section{Daftar Pustaka}

Azhar, Rofa Yulia. 2012. "Perkebunan Kelapa Sawit, antara Ekonomi dan Ekologi". Artikel dalam BBC, 21 Juni 2012.

Chaer, Abdul dan Agustina Leony. 2004. Sosiolinguistik: Perkenalan Awal. Jakarta: Rineka Cipta.

Derni, Ammaria. 2008. "The Ecolinguistic Paradigm: An Integrationist Trend in Language Study". Tlemcen: Abou Bekr Belkaid University Algeria The International Journal of Language Society and Culture. www.educ.utas.edu. au/users/tle/JOURNAL/

Drakare, Stina; Lennon, Jack J.; Hillebrand, Helmut. 2006. "The imprint of the geographical, evolutionary and ecological context on species-area relationships". Ecology Letters 9 (2): 215-227. doi:10.1111/j.14610248.2005.00848.x. PMID 16958886. [http://id.wikipedia.org/wiki/ Keanekaragaman_hayati\#], diunduh 1 Juni 2013, pukul 21.35 WIB.

Gabriel, Sigmar. 2007. "30\% of all species lost by 2050 ", BBC News, 9 Maret 2007. [http://id.wikipedia.org/wiki/Keanekaragaman_hayati\#], diunduh 1 Juni 2013, pukul 21.45 WIB.

Herman RN. "Kepunahan Bahasa" [suara_tinda.com], diunduh 12 September 2012, pukul 15.05 WIB.

Jim Chen. 2003. "Across the Apocalypse on Horseback: Imperfect Legal Responses to Biodiversity Loss". The Jurisdynamics of Environmental Protection: Change and the Pragmatic. Environmental Law Institute. hIm. 197. ISBN 1-58576-0714. [http://id.wikipedia.org/wiki/Keanekaragaman_hayati\#cite], diunduh 2 Juni 2013, pukul 11.15 WIB.

Jorgensen, S.E and G. Bendoricchio. 2001. Fundamentals of Ecological Modelling. Third Eddition. Oxford. Elsevier Science Ltd. The Boulevard, Longford Land Kidlington.

Louis dan Jean Calvet. 2006. Towards An Ecology of World Languages. 65 Bridge Street Cambridge: Polity Press.

Mbete, Aron Meko. 2009. "Problematika Keetnikan dan Kebahasaan dalam Perspektif Ekolinguistik". Sebuah refleksi ringan (artikel).

Merchant, Carolyn. 1992. Livable World: Timber Company You Are Selling Our Home. New York : Routledge. An Imprint of Routhledge, Chapman \& Hall.Inc 29 West 35th Street NY 10001

Paul Ehrlich dan Anne Ehrlich. 1981. Kepunahan, Random House, New York. ISBN 0-394-51312-6, [http://id.wikipedia.org/wiki/Keanekaragaman_hayati\#], diunduh 2 Juni 2013, pukul 11.50 WIB.

Pimm, S. L.; Russell, G. J.; Gittleman, J. L.; Brooks, T. M. 1995. "The Future of Biodiversity" (PDF). Science 269 (5222): 347-350. doi:10.1126/ science.269.5222.347. PMID 17841251. Bibcode: 1995Sci...269..347P. [http://id.wikipedia.org/wiki/Keanekaragaman_hayati\#], diunduh 2 Juni 2013, pukul 12.10 WIB.

56 | Ranah, Volume 2, Nomor 1, Juli 2013 
Sanderson, James; Moulton, Michael. 1998. Wildlife Issues in a Changing World, Second Edition [Paperback]. CRC Press. ISBN 978-1-56670-351-2. [http:// id.wikipedia.org/wiki/Keanekaragaman_hayati\#], diunduh 2 Juni 2013, pukul 14.03 WIB.

Sugiyono. 2008. Metode Penelitian Kuantitatif Kualitatif dan R\&D. Bandung: Alfabeta.

Suparna, Stephanus, dkk. (Tim Redaksi). 2009. Mengenai Nusantara: Provinsi Sumatera Utara. Bekasi: Sari Ilmu Pratama. 